\title{
New strategy for the optimal design and manufacture of high performance milling heads ${ }^{(\cdot)}$
}

\author{
A. Bustillo*, L.M. Plaza** and M. Rodríguez***
}

\begin{abstract}
High-performance mechanical-transmission heads are one of the most complex, costly and problematic parts of a milling machine, owing to the large amount of piping required for transporting fluids and to the high level of mechanical performance that is required from them. This study proposes a strategy for optimising the design and manufacture of head bodies by using aluminium alloys and by integrating tubular stainless steel inserts in the casting of the head. These tubular inserts that are integrated into the aluminium mass are an alternative to cooling conduits currently made by machine drilling. As demonstrated in the experimental validation of the first prototype, the new method has created a design that retains the same mechanical performance, increases its reliability and reduces the weight of the milling machine's moving parts.
\end{abstract}

\section{Nueva estrategia para el diseño y fabricación de cabezales de fresadora de altas prestaciones}

\begin{abstract}
Resumen
Los cabezales de transmisión mecánica de altas prestaciones son una de las partes más complejas, costosas y problemáticas de una maquina fresadora. Esto es debido a la gran cantidad de canalizaciones para la transmisión de fluidos que deben de contener y a las altas prestaciones mecánicas que se les exigen. En este trabajo se presenta una estrategia para optimizar el diseño y la fabricación de los cuerpos de estos cabezales basada en la incorporación de aleaciones de aluminio y la inclusión de insertos tubulares de acero en la propia fundición que conforma el cabezal. Los insertos tubulares sustituyen a los canales de refrigeración realizados actualmente por taladros de mecanizado y quedan integrados en la masa de aluminio. La nueva metodología ha permitido realizar un diseño que mantiene las prestaciones mecánicas, aumenta la fiabilidad y reduce la masa de estos elementos móviles de fresadoras como ha demostrado la validación experimental de un primer prototipo.
\end{abstract}

Palabras clave

Cabezal de fresado; Diseño; Análisis por elementos finitos; Fundición de aluminio; Insertos de acero inoxidable.

\section{INTRODUCTION}

The European Committee for Co-operation of the Machine Tool Industries CECIMO ${ }^{[1]}$ has reported significant growth over the past five years in the number of large-scale dynamic milling machines equipped with high-performance milling heads, which is associated with the expansion of the wind-energy sector described by De Vries ${ }^{[2]}$. New research is required on these machines that should focus, in general, on their large vertical dimensions, but also on developing new heads that satisfy the requirements of the wind-energy sector and the modelisation of the cutting process ${ }^{[3]}$. These machines incorporate high-accuracy indexing (less than $0.5^{\circ}$ ), mechanicaltransmission, high-speed (up to 6,000-8,000 rpm), high-power (over $25 \mathrm{KW}$ ) heads. The studies of the US Department of Energy ${ }^{[4]}$ on wind turbine manufacturing requirements confirm that it is especially important to maintain the high precision of these heads, by ensuring that there is no deformation due to machining forces or heat sources that introduce an angular displacement greater than $0.006^{\circ}$ of the tool tip.

\footnotetext{
(.) Trabajo recibido el 07 de enero de 2011 y aceptado en su forma final el día 09 de junio de 2011.

* Nicolas Correa S.A., C/ Alcalde Martín Cobos 16B, 09007 Burgos, Spain, E-mail: a.bustillo@correaanayak.es.

** Inasmet-Tecnalia, Paseo Mikeletegi 2, 20009 San Sebastián, Spain. E-mail: Iplaza@inasmet.es.

*** Fatronik-Tecnalia, Paseo Mikeletegi 7, 20009 San Sebastián, Spain. E-mail: mrodriguez@fatronik.com.
} 
These heads are formed by two very different structures: the head bodies and the power and rotation drive chain. With respect to the head bodies, new solutions need to be developed that provide high thermal stability, high mechanical stiffness, reduced weight and high reliability. High thermal stability is required to assure the precision needed for the head. High mechanical stiffness is required to assure that the transmission of high cutting forces does not generate deformation and loss of precision. Sekler et al. ${ }^{[5]}$ demonstrated that reduced mass is required because the heads are moving elements of the machine, and the life-cycle environmental impact of the machine must be reduced. More recently, Dietmar et al. ${ }^{[6]}$ established that the energy consumed when these machines are in use amounts to $95 \%$ of the ecological impact of their total life-cycle. Increased reliability is fundamental as any failure in the operation of a head means immediate stoppage of the milling machine, which entails a significant loss in productivity.

The bodies of conventional high-power milling heads have many internal, complex-geometry conduits. These conduits serve to remove the heat produced by the drive chain and to transport liquids for lubricating the bearings and the tool. These conduits feature complex geometries to provide the head with high thermal stability. In practice, this requirement means that head bodies are cast solid, and then multiple drilling operations create the conduits. As these conduits are not straight, multiple drilling operations are required to create one conduit, and several of these drillholes will need to be partially sealed. The internal meeting point of these drillholes entails an additional problem: this point is not usually exact enough, which gives rise to a blind section of conduit that can collect swarf from drilling that, owing to the operating cycles of the head, can be dragged toward the head ball bearings, which causes ball bearing damage and a reduction in head reliability.

Added to this industrial need is the fact that milling machine manufacturers are medium-sized companies. Small casting runs are therefore carried out, usually of about 150 heads per year, which is not conducive to the design of large tools for improving the design or manufacture of these head bodies.

\section{NEW DESIGN AND MANUFACTURE STRATEGY}

To create a new design for head bodies that meets the industrial needs described above, a new methodology was developed in four steps:
- Selection of a new material for manufacturing the head bodies. This material should meet the mechanical requirements of the head, and should melt at a sufficiently-low temperature for tubular inserts of another metal to be added during casting.

- Redesign of the bodies maintaining the geometric dimensions required for the new bodies to be compatible with the rest of the head design (drive chain, etc.). Mechanical performance must also be similar to that of previous heads and the mass must be reduced as much as possible as confirmed in Dietmar and Verl's study ${ }^{[7]}$. It is also important to maintain the characteristic industrial design of the head. Finite element simulation is used at this stage.

- Design of the pipes and the manufacturing process: CAD software is used to design the tubular inserts. The tubular inserts are built to these 3D drawings using folding machines and welding joints where the geometry is more complex. PROCAST ${ }^{\mathrm{TM}}$ software is used to carry out simulations to test the correct operation of the feed and mould-filling process.

- Experimental validation of the design and manufacturing processes: the new head is fitted to a real milling machine and tests are run. Mechanical stiffness of the machine and its vibration modes are measured. Lastly, rigorous machining tests are carried out to assure the performance of the new head under real operating conditions.

To date, this integral strategy has not been used for the design of milling-machine head bodies. For the modelling of the head bodies, there are three well-established types of dynamic structural analysis techniques: the distributed-mass beam method proposed by Hijink and Van Der Wolf ${ }^{[8]}$, the lumpedconstant beam method proposed by Taylor and Tobias $^{[9]}$ and the Finite Element Method (FEM) proposed by Sato et al. ${ }^{[10]}$. Each of these methods can estimate the dynamic behaviour of an elastic structure when its form is known. Sato et al. ${ }^{[9]}$ studied calculation time for the FEM and concluded that it is longer than the calculation time of the other two types because of the complexity of FEM modelling, but the FEM gives reasonably good results for complex geometries. Furthermore, it has been demonstrated that using the FEM for modelling milling machines is an appropriate technology for the modelling of milling machines as a whole. Te-Yen and Lee ${ }^{[11]}$ used it for modelling a conventional milling machine, Zhang et al. ${ }^{[12]}$ for a High-Speed 
milling machine and Lopez de Lacalle and Lamikiz ${ }^{[13]}$ refers it as a standard technique for this task. The same technique is also considered useful for modelling elements that are particularly critical for final machining precision, such as Amaral et al. ${ }^{[14]}$ demonstrates for the systems for fixing the piece and Rantatalo et al. ${ }^{[15]}$ for spindles. Yang et al. ${ }^{[16]}$ have also studied FEM modelling of milling heads for optimising their design.

Although there is interest in the industrial incorporation of new materials in the structural elements of conventional milling machines, such as heads, as is confirmed in a study by Smolik [17], there are no real applications of light alloys for high-torque and high-performance heads. Likewise, including tubular inserts for conveying fluids is yet to appear in the bibliography for milling heads. Love and Goodship $^{[18]}$ analysed the performance of multimaterial injection moulding. There are also studies about the performance of multimaterial powder injection moulding, in this case Liu et al. ${ }^{[19]}$ did it for an Al-AlN metal matrix composite, Heaney et al. ${ }^{[20]}$ for tool steel and boron doped austenitic stainless steel, Imgrund et al. ${ }^{[21]}$ for non-magnetic and a ferromagnetic stainless steel and Liu et al. ${ }^{[22]}$ for aluminium (Steel and Magnet) Hybrid components. These technologies have been found to have several problems: melting of the metallic inserts, degradation of insert properties, component cracking owing to mismatches in the coefficient of thermal expansion, and severe interfacial reactions between the insert and host material like Liu et al reported ${ }^{[22]}$. To date the following technology has been proposed for aluminium-steel hybrids: laser brazing by Mattei et al. ${ }^{[23]}$ electron beam welding by
Bach et al. ${ }^{[24]}$ and powder injection moulding by Liu et al. ${ }^{[19]}$.

A UAD head from the company Nicolas Correa S.A. was chosen to validate the new design and manufacture strategy. This is a Huré-type head with a maximum rotational speed of up to $6,000 \mathrm{rpm}$, maximum torque of $1,045 \mathrm{Nm}$ and power of $30 \mathrm{KW}$. The head has an angular indexing positioning system with a precision of $0.1^{\circ}$ on both axes. This head was chosen as a large number -around 200 - of them are manufactured each year. The two bodies of this head currently weigh $184 \mathrm{~kg}$, while the total weight of the head is $592 \mathrm{~kg}$. It is made out of GGG-50 cast iron (Fig. 1).

Heads are currently made by gravity-pour sand casting. The subsequent finishing is done by machining all head surfaces (two parts: head and intermediate body). This includes the face milling of the contact surfaces with the machine and the Hirth couplings and all drillholes that constitute the conduits for cooling and conveying liquid to the tool tip.

The operating temperature of this head is in the range of $-2{ }^{\circ} \mathrm{C}$ and $+15^{\circ} \mathrm{C}$ with respect to ambient temperature. If malfunctioning causes the head to reach more than $15^{\circ} \mathrm{C}$ above ambient temperature and the cooling system cannot lower the temperature, the machine's numeric control immediately stops milling machine operation.

For the head design and operating conditions outlined above, the head bodies must meet the following requirements. From a structural point of view, the alloy must have a minimum compressivetensile strength of $250 \mathrm{MPa}$ with an elongation of greater than $3 \%$ to avoid breakages. These
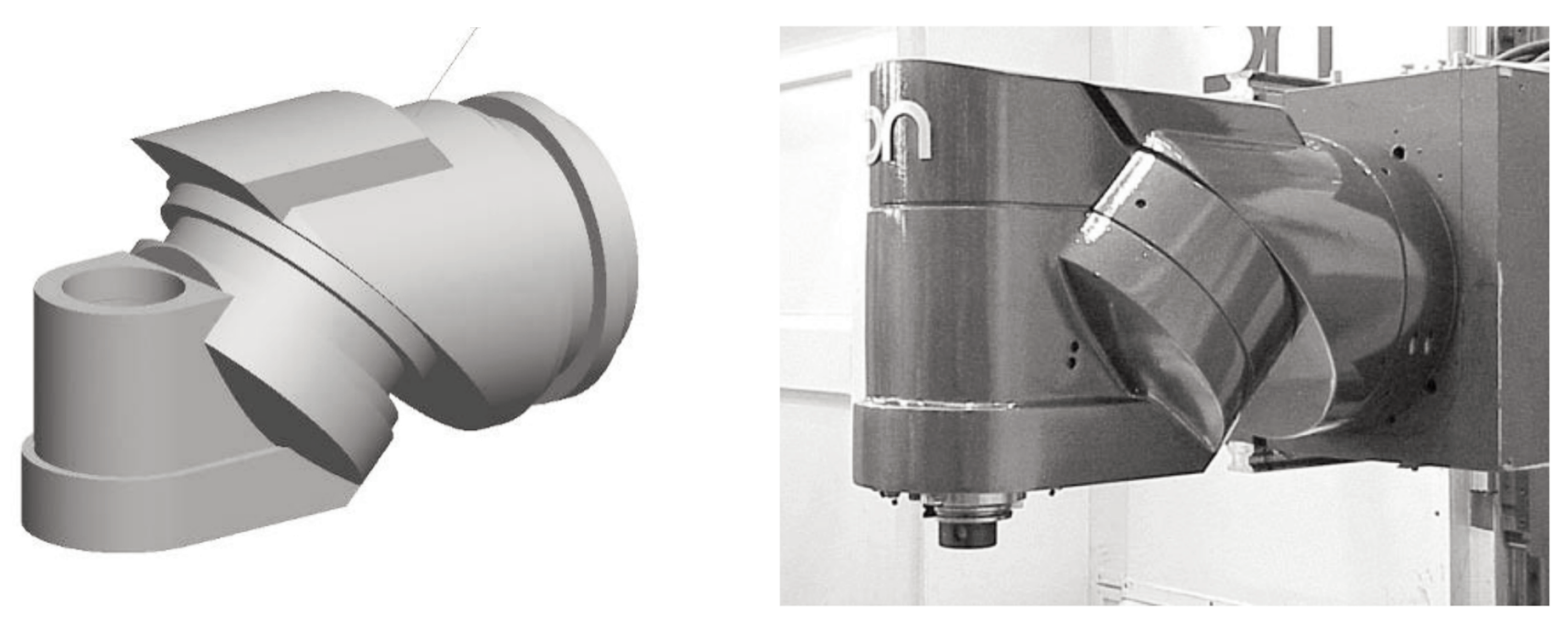

Figure 1. Current UAD head bodies in cast iron.

Figura 1. Diseño actual de los cuerpos del cabezal UAD en fundición de hierro. 
characteristics must be accompanied by an angular deformation of the head of less than $10 \mu \mathrm{m} / \mathrm{m}$ or, similarly, $0.006^{\circ}$ at the tool tip and an expansion per axis of less than $10 \mu \mathrm{m} /{ }^{\circ} \mathrm{C}$ to avoid incorrect positioning of the head. The cast bodies must have good internal soundness with a degree of porosity of less than $20 \mathrm{cc} / \mathrm{kg}$ of material to assure the leaktightness of the part. The critical areas should be free from pores and defects, such as micro shrinkages, inclusions, oxides, etc. Critical areas are exterior surfaces that have to be milled, drilled or threaded for assembly. Lastly, in the manufacturing process, each head body must have a correct position with a displacement of less than a hundredth of the outlet points to the exterior of the cooling system so they are always positioned with the same coordinates to facilitate connection with other parts of the head.

\section{CHOICE OF ALLOY}

One of the objectives of this study was to replace GGG-50 cast iron with a lighter material and to replace the machining of the cooling conduits with tubular inserts. The decision was made to use an aluminium alloy because of its lightness compared to the previous material; its melting point, which is significantly lower than that of other metals; its good pouring quality and its ease of machining.

There are very many aluminium alloys and, it is therefore necessary to choose the one that best meets the specifications of the head-manufacturing process and the in-service operating conditions: job frequency, forces borne, vibrations and temperatures. The critical parameters for choosing the most appropriate alloy are twofold: mechanical characteristics and technological properties (pourability, corrosion resistance and machinability). A short-list of five alloys was made with values that are particularly appropriate in terms of these variables as shown in table I extracted from Bertrand's work ${ }^{[25]}$.

Out of the selected alloys, two were chosen for carrying out -along with the material currently used (GGG-50)- simulations of the static, dynamic and thermal behaviours of the head to make a decision on which was the best for final manufacturing. The following section outlines these studies. The AU5GT and AS13UG alloys were chosen. These alloys have a good pourability and an acceptable mechanical strength at high temperatures (of up to $80^{\circ} \mathrm{C}$ ), basic characteristics for the manufacturing process and in-service behaviour respectively.

\section{REDESIGN OF HEAD EXTERIOR AND SIMULATION OF ITS BEHAVIOUR}

As described in section 2, the second stage of the proposed design strategy consisted in redesigning the head bodies, while maintaining the geometric dimensions so that the new bodies would be compatible with the rest of the head. The redesign process was carried out as follows:

- Generation of the finite element model.

- Application of the contour and load conditions.

- Calculation of the stiffness, displacements and tensions.

Table I. Main characteristics of the aluminium alloys shortlisted for the head ${ }^{[25]}$

Tabla I. Principales características de las aleaciones de aluminio más apropiadas para el nuevo cabezal [25]

\begin{tabular}{|c|c|c|c|c|c|}
\hline Alloy properties & AS13 & AU5GT & AS7G & AS9U3 & AS13UG \\
\hline Density $\mathrm{g} / \mathrm{cm}^{3}$ & & 2 & 2.6 & 2. & 2.68 \\
\hline $\begin{array}{l}\text { Elasticity } \\
\text { Pourabil }\end{array}$ & & & & 00 & 70 \\
\hline $\begin{array}{r}(1 \mathrm{~L} \\
\text { Interna }\end{array}$ & 5 & 3 & 4 & 4 & 5 \\
\hline (1 Lon & 1 & 5 & 2 & 2 & 1 \\
\hline Expansion coefficient $\left(\times 10^{-6}\right)$ & 20 & 23 & 21.5 & 20.5 & 20 \\
\hline Tensile strength (MPa) & 190 & 400 & 300 & 320 & 350 \\
\hline Manufacturing process & Mould & Sand & All & Injection & Sand \\
\hline Machinability (1 Bad - 5 Good) & 1 & 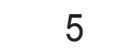 & 4 & 4 & 2 \\
\hline
\end{tabular}


- Calculation of the frequencies and vibration modes.

- Thermal calculation.

- A study of flexibilities that involved finding out the contribution of each component to the total deformation at the tool tip. Overall stiffness is determined by the stiffness of the most flexible element; therefore, it was important to devote time to optimising the most flexible elements.

- Making changes to optimise the head and its performance.

- Calculation of total stiffness, modes and frequencies, displacements and tensions under load conditions.

- Comparison of results and deciding whether to accept the change. To make the decision on the change, the mass/stiffness ratio and the value of thermal deformations were taken. Those solutions in which the contributed mass was not associated with an increase of at least the same percentage in stiffness and in which the thermal deformations increased were considered unacceptable.

\subsection{Finite element model}

A finite element model of the UAD head was generated using Nastran/Patran ${ }^{\circledR}$ software. This model is shown in figure 2.

The head bodies were modelled as higher-order tetrahedron 3D elements (ten nodes per element, three degrees of freedom per node), and their weight and stiffness were taken into account. The drive chain components were modelled as lumped masses located at their centres of gravity; the stiffnesses of these components were not included in the model because their stiffness values were much greater than those of the bodies.

A convergence analysis was performed to select the size of the mesh that provides accurate and reliable results and, in turn, requires less calculation time. To do so, finite element meshes of different densities were generated and the number of degrees of freedom, calculation time and the results were recorded. Note that calculation time is directly determined by the number of degrees of freedom, which is determined by the number of nodes in the mesh and the degrees of freedom for each node. The number of degrees of freedom for each node depends on the type of mesh element selected (plate or solid element of lower or higher order). Table II shows the characteristics of the two mesh densities under study and their respective results.

The density of mesh 1 (model 1) provides results the precision of which is very similar to those obtained for mesh 2 (model 2) and a $56 \%$ shorter calculation time, on which basis the mesh density in model 1 was chosen.

\subsection{Contour conditions and load conditions}

The contour conditions modelled a perfect join between the head and the ram at the points in which the joint screws of both parts are found.

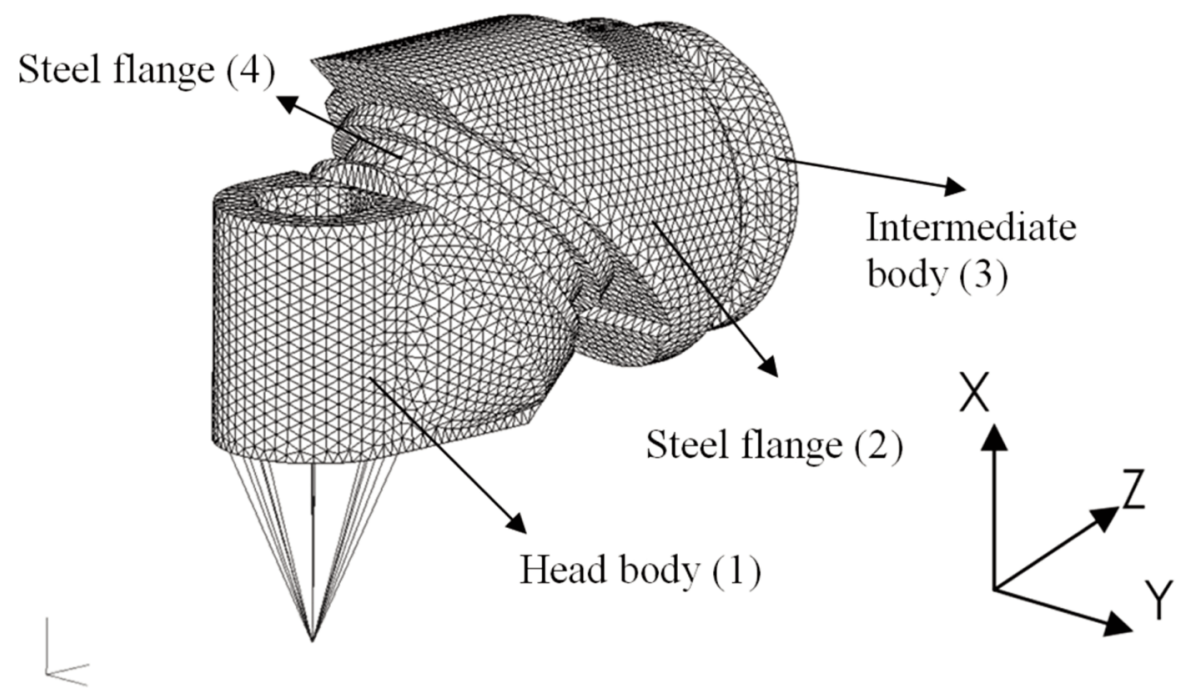

Figure 2. Finite element model of the head bodies.

Figura 2. Modelo de elementos finitos de los cuerpos del cabezal. 
NEW STRATEGY FOR THE OPTIMAL DESIGN AND MANUFACTURE OF HIGH PERFORMANCE MILLING HEADS NUEVA ESTRATEGIA PARA EL DISEÑO Y FABRICACIÓN DE CABEZALES DE FRESADORA DE ALTAS PRESTACIONES

Table II. Characteristics of the two mesh densities under study and the results obtained in each case

Table II. Características de las dos densidades de las mallas estudiadas y resultados obtenidos para cada caso

\begin{tabular}{lcc}
\hline & Model 1 & Model 2 \\
\hline $\begin{array}{l}\text { Type of element } \\
\text { Number of nodes }\end{array}$ & TET10 & TET10 \\
Calculation time & 222642 & 344155 \\
& $53^{\prime}$ & $1 \mathrm{~h} 35^{\prime}$ \\
\hline Load applied & Displacement at the tool tip $(\boldsymbol{\mu m})$ \\
\hline Fx $=1000 \mathrm{~N}$ & 2.04 & 2.06 \\
$\mathrm{Fy}=1000 \mathrm{~N}$ & 4.73 & 4.82 \\
$\mathrm{Fz}=1000 \mathrm{~N}$ & 3.64 & 3.76 \\
\hline
\end{tabular}

The following load conditions were studied:

Static calculation: forces of $1000 \mathrm{~N}$ at the tool tip in three directions, in addition to a final case to observe the influence of own weight (gravity).

- Static calculation for forces equivalent to a roughing cutting test of $7900 \mathrm{~N}$. The axial force was taken as $25 \%$ of the cutting force, $2000 \mathrm{~N}$, and the feed force, as $75 \%, 5900 \mathrm{~N}$.
- Calculation of natural frequencies and vibration modes.

- Thermal calculation: application of heat spotlights $\left(60^{\circ} \mathrm{C}\right.$ on the tool tip and $35^{\circ} \mathrm{C}$ on the internal faces).

- Thermal calculation: Unit change in ambient temperature.

Table III. Deformations under static loads for the selected alloys

Tabla III. Deformaciones bajo cargas estáticas para las dos aleaciones seleccionadas

\begin{tabular}{lccc}
\hline & & \multicolumn{2}{c}{ Material } \\
\cline { 3 - 4 } Study case & Result in & AU5GT & AS13UG \\
\hline Fx $=1000 \mathrm{~N}$ at TCP & $\mathrm{Kx}(\mathrm{N} / \mu \mathrm{m})$ & 309 & 326 \\
$\mathrm{Fy}=1000 \mathrm{~N}$ at TCP & 123 & 131 \\
$\mathrm{Fz}=1000 \mathrm{~N}$ at TCP & $\mathrm{Ky}(\mathrm{N} / \mu \mathrm{m})$ & 151 & 162 \\
& $\Delta \mathrm{N} / \mu \mathrm{m})$ & 5 & 4.8 \\
Gravity & $\Delta \mathrm{y}(\mu \mathrm{m})$ & - & - \\
& $\Delta \mathrm{z}(\mu \mathrm{m})$ & 4.8 & 4.5 \\
Roughing cutting test & $\Delta \mathrm{x}(\mu \mathrm{m})$ & 33 & 31 \\
Fc $=7900 \mathrm{~N}$ (Fz); Fax $=2000 \mathrm{~N}$ & $\Delta \mathrm{y}(\mu \mathrm{m})$ & 47 & 44 \\
(Fx); Fav 5900 N (Fy) & $\Delta \mathrm{z}(\mu \mathrm{m})$ & 59 & 55 \\
Total weight without considering lumped masses $(\mathrm{kg})$ & 188 & 185 \\
& $\mathrm{X}$ direction & 0.6 & 0.56 \\
weight/stiffness ratio & Y direction & 1.5 & 1.4 \\
& $\mathrm{Z}$ direction & 1.2 & 1.1 \\
\hline
\end{tabular}


Table IV. Natural frequencies for the selected alloys

Tabla IV. Frecuencias naturales para las dos aleaciones estudiadas

\begin{tabular}{llll}
\hline Frequencies $(\mathbf{H z})$ & $\boldsymbol{\omega 1}$ & $\boldsymbol{\omega 2}$ & $\boldsymbol{\omega 3}$ \\
\hline AU5GT & 251 & 277 & 726 \\
AS13UG & 259 & 285 & 749 \\
\hline
\end{tabular}

\subsection{Choice of aluminium alloy}

A first study was undertaken maintaining current head geometry and changing the body materials to select the most suitable aluminium alloy out of the two shortlisted in Section 3. Tables III and IV show the deformations obtained for both materials under static load conditions and the natural frequencies obtained. Table $\mathrm{V}$ shows the angular deformation of the tool with respect to the vertical axis (tool axis) under thermal load conditions.

Tables III-V demonstrates that alloy AS13UG has better static, dynamic and thermal behaviours than alloy AU5GT. The only aspect in which the AU5GT alloy is better is its greater creep resistance (400 MPa compared with $350 \mathrm{MPa}$ ). However, the maximum tensions generated under the different load cases do not exceed $20 \mathrm{MPa}$, which means the creep resistance parameter is not decisive in this analysis. For the above-mentioned reasons, alloy AS13UG was chosen for the redesign study.

\subsection{Study of flexibilities}

An analysis of flexibilities was carried out on each of the four main bodies of the head (the two aluminium bodies and the two steel flanges) to find out the flexibility added by each to deformation at the tool tip. The study of flexibilities listed in table VI revealed that:
Table V. Angular deformations before thermal changes for the selected alloys

Tabla V. Deformaciones angulares bajo cargas térmicas para las aleaciones estudiadas

\begin{tabular}{|c|c|c|}
\hline Study case & AU5GT & AS13UG \\
\hline $\begin{array}{l}\text { TCP } 60^{\circ}+\text { internal faces } \\
35^{\circ} \mathrm{C} \\
\text { Deformation by unit change }\end{array}$ & $0.05^{\circ}$ & $0.049^{\circ}$ \\
\hline in ambient temperature & $0.0026^{\circ}$ & $0.0024^{\circ}$ \\
\hline
\end{tabular}

- The intermediate body (3) is the most flexible component in the $\mathrm{X}$ direction, accounting for $50 \%$ of all deformation in this direction.

- The head (1) and the intermediate body (3) are the most flexible components in the $\mathrm{Y}$ direction, accounting for $36 \%$ and $30 \%$ of all deformation in this direction.

- The head (1) and the intermediate body (3) are the most flexible components in the $\mathrm{Z}$ direction, each providing $35 \%$ of the deformation in this direction.

As table VI shows, the $\mathrm{Y}$ and $\mathrm{Z}$ directions were the most flexible directions of the head. It was, therefore, decided to modify the head body (1) and the intermediate body (3) to increase their stiffness in these directions.

\subsection{Making the modifications and accepting the changes}

Different modifications were made to the external geometry of the head bodies, and their behaviour was analysed under the defined static, dynamic and thermal load conditions. The changes that provided an

Table VI. Flexibility study of the new head

Tabla VI. Resultados del estudio de flexibilidades del Nuevo cabezal

\begin{tabular}{lccc}
\hline Head components & $\begin{array}{c}\text { \% Stiffness } \\
\text { in X }\end{array}$ & $\begin{array}{c}\text { \% Stiffness } \\
\text { in Y }\end{array}$ & $\begin{array}{c}\text { \% Stiffness } \\
\text { in Z }\end{array}$ \\
\hline Head body (1) & 9 & 36 & 35 \\
Steel flange (2) & 12 & 16 & 17 \\
Intermediate body (3) & 50 & 30 & 35 \\
Steel flange (4) & 29 & 18 & 13 \\
\hline
\end{tabular}



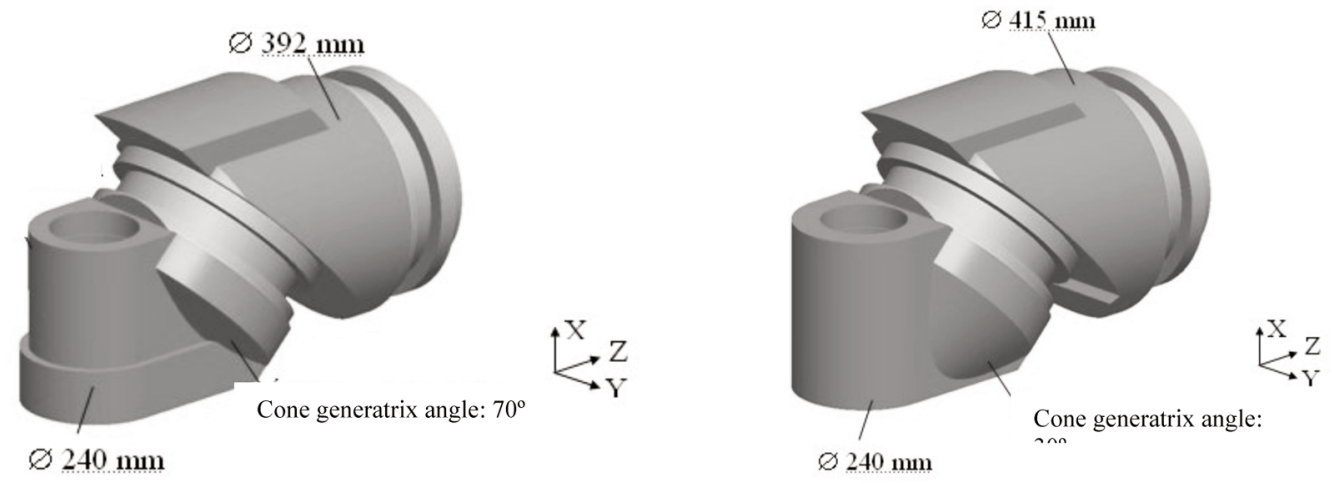

(a)

$\varnothing 240 \mathrm{~mm}$

$\varnothing 240 \mathrm{~mm}$

(b)

Figure 3. 3D models of initial head (a) and new head design (b).

Figura 3. Modelos 3D del cabezal inicial (a) y del nuevo diseño (b).

improved weight/stiffness ratio and less deformation under thermal loads were accepted. Solutions in which the added weight did not provide an increase in stiffness by at least the same percentage and those in which the thermal deformations increased were discarded.

The final design of the optimised head is $16 \%$ lighter than the nodular cast-iron head (489 kg instead of $592 \mathrm{~kg}$ ) and complies with the desired requirements of weight, mechanical, stiffness and thermal stability: the angular deformation of the head under thermal loads is $0.0002 \%{ }^{\circ} \mathrm{C}$; and, mechanical stiffness is $\mathrm{Kx}=354 \mathrm{~N} / \mu \mathrm{m}, \mathrm{Ky}=155 \mathrm{~N} / \mu \mathrm{m}, \mathrm{Kz}=180 \mathrm{~N} / \mu \mathrm{m}$. Figure 3 shows initial and final head design.

\section{REDESIGN OF HEAD INTERIOR AND POURING SIMULATION}

The interior design of the new head includes metallic tubular inserts, which means all the cooling and lubrication conduits are added during head manufacture, making the post-manufacturing of these conduits redundant (Fig. 4). The interior design of the head bodies was done when the manufacturing process was designed. For this reason, it was necessary to design the sand mould feeding and filling method described by Mikelonis ${ }^{[26]}$. The manufacturing process was assisted by the analyses obtained with the simulation systems (PROCAST ${ }^{\mathrm{TM}}$ ) of the feed and filling system to test and guarantee the internal soundness of the manufactured part. Metal contraction was also taken into account during the casting process to achieve the desired final geometry. For the simulation of mould feeding and filling, the geometry of the mould was discretized via a tetrahedron finite element mesh made up of 628,228 elements and 115,679 nodes. The initial temperature for the part was set at $680^{\circ} \mathrm{C}$. The materials used in the simulation were the alloy AS13UG and sand mould used in manufacturing.
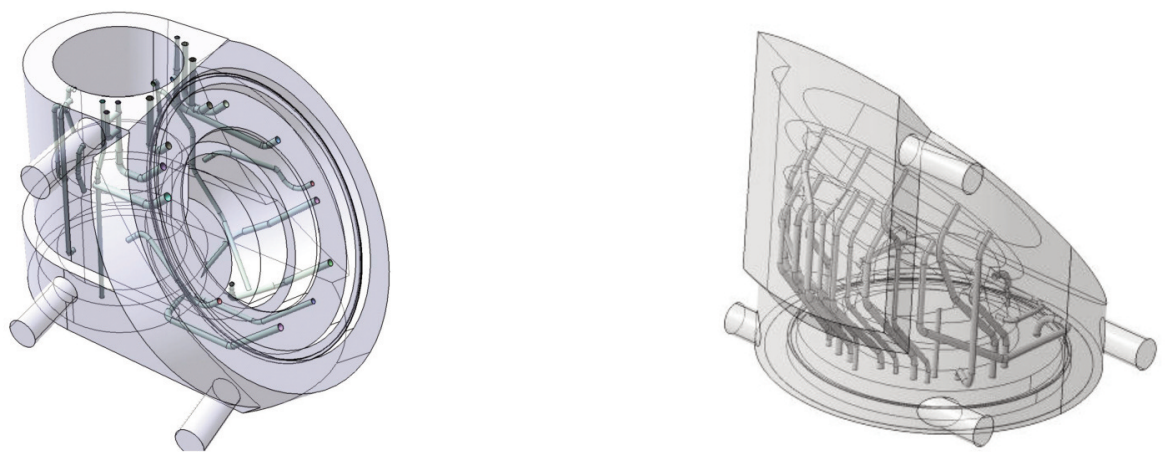

Figure 4. Tubular inserts in the head and intermediate bodies.

Figura 4. Insertos tubulares en los dos cuerpos del nuevo cabezal. 
After simulation of the feed process, the mechanical design allowing the correct positioning of the metallic cooling inserts was done. The system for anchoring the pipes in the mould had to ensure that, during the filling of the mould with liquid metal, the pipes were not deformed or displaced. For this reason, the mould design incorporated special marks consisting of exterior supports for the tubular inserts added in the material that could resist the temperatures produced in the melting process without deforming.

Once the manufacturing process was designed and the aluminium alloy was chosen, the most suitable materials for the tubular inserts and the surface protector coating were selected. Copper, aluminium and stainless steel were considered for these inserts. This choice was fundamental owing to the soluble behaviour of iron and aluminium. To select the most suitable material, actual gravity-pour tests in small sand moulds were undertaken (Figs. 5 and 6), the aim of which was to test pipe leak-tightness, resistance to liquid metal and surface adhesion to aluminium (interface quality).

To carry out these tests, the copper and aluminium inserts were coated with different refractory paints to safeguard against the liquid-metal attack and possible perforation of the pipes. In some cases, the inserts were also filled with salt or sand to avoid deformation during mould filling. The results of the tubular insert tests appear below in table VII.

The tests with aluminium pipes gave negative results as the pipes partially melted during pouring. The result for stainless steel was very good; the pipe stayed intact and the adhesion with aluminium was

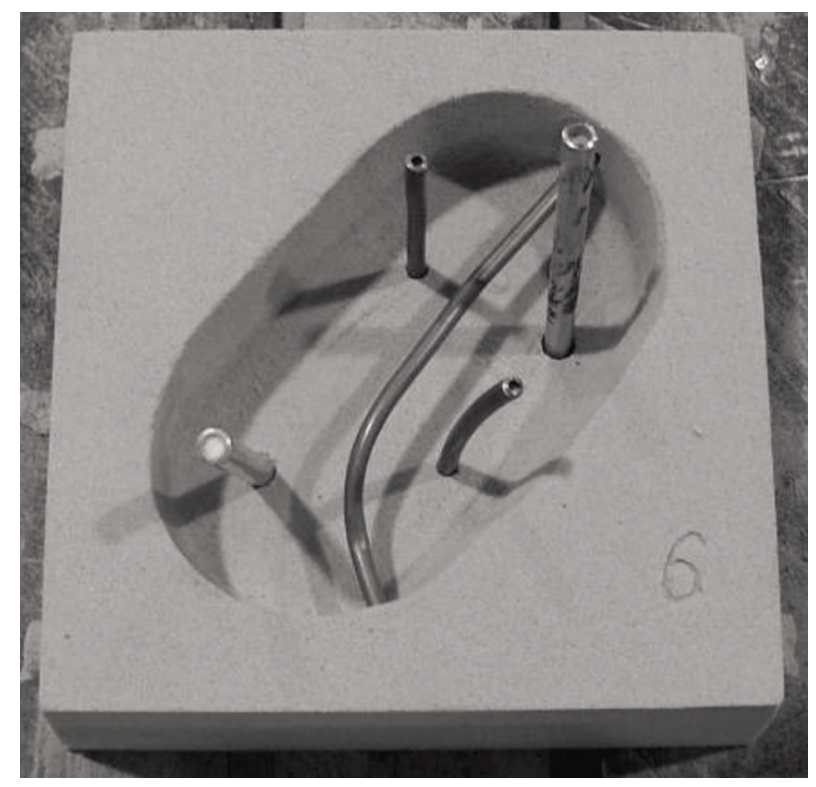

Figure 5. Small sand mould with tubular inserts and pouring basin.

Figura 5. Molde de arena para los insertos tubulares y la colada.

optimum. The results for copper depended heavily on the coating and the filling. The silica paint did not withstand the liquid-aluminium attack; aluminium oxide fared better, but small pores were produced. With graphite paint, the results were positive without the appearance of pores or the effects of the coating attack. Based on these results stainless steel was chosen for manufacturing the tubular inserts.

Table VII. Pouring tests

Tabla VII. Pruebas de colada

\begin{tabular}{lccc}
\hline Pipe material & Coating & Filling & Result \\
\hline Copper & Aluminium & None & regular \\
Copper & oxide & None & regular \\
Copper & Silica & None & negative \\
Copper & Graphite & None & very good \\
Copper & None & None & negative \\
Copper & None & Sand & regular \\
Copper & None & Sand & regular \\
Stainless steel & None & None & very good \\
Aluminium & None & None & negative \\
Aluminium & None & Salt & negative \\
Aluminium & None & Sand & negative \\
Aluminium & Graphite & None & negative \\
\hline
\end{tabular}



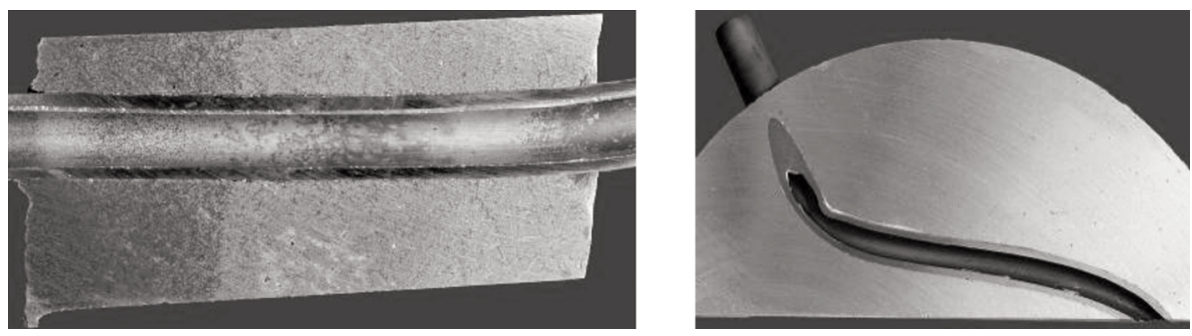

Figure 6. Sections of the pouring tests.

Figure 6. Secciones de los ensayos de colada.

\section{HEAD MANUFACTURE AND EXPERIMENTAL VALIDATION}

Once all the parameters of the process, mould type (sand) and the filling method (gravity) were defined, the manufacture of the prototypes began. The process had several stages. Firstly, the models/moulds were manufactured in wood (Fig. 7) and the tubular inserts were shaped as per the construction plans (Fig. 8). The moulds and cores were then made in silica sand via chemical forging. The next operation was to put the tubular inserts in the sand moulds and fix them to the sand cores and the marks with an adhesive used in casting.

Once the tubular inserts were fixed in place, the core was fitted in a half-mould, and the mould was closed with the upper half-mould and sealed with the above-mentioned adhesive. Once the aluminium ingots were melted in the melting furnace, the key operation in the process took place: the manufacture of the part (head or intermediate body) via gravity casting, i.e., filling (by pouring) the mould with liquid aluminium.

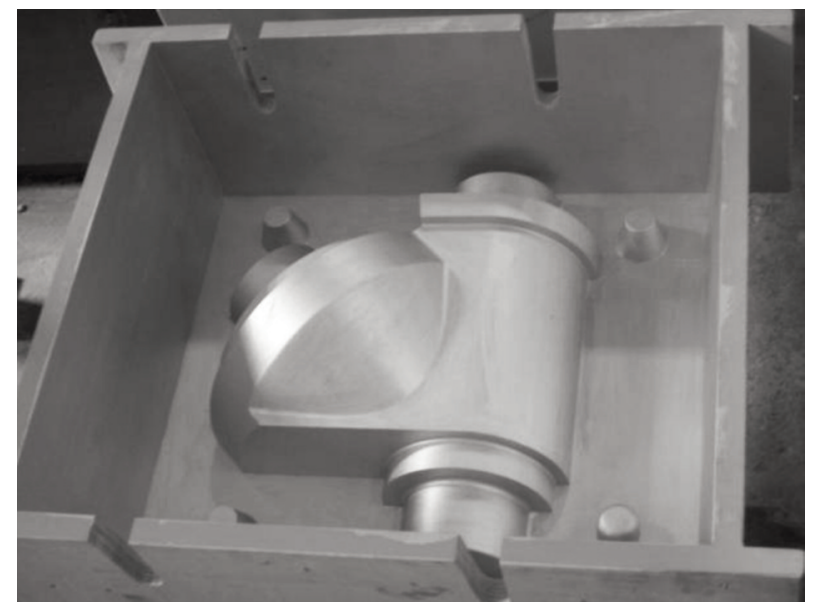

Figure 7. Wood model.

Figura 7. Modelo en madera.
The following stage in the process comprised removing the mould by getting rid of the sand from the half-moulds and the core, the separation was done by cutting the launders and headers from the part. The last step was the finishing of the part, which was done by machining. This included the face milling of the contact surfaces with the machine and the cogs and all drilling for creating the conduits for cooling and conveying liquid to the tool tip. Table VIII contains the times required for these operations for the standard and the new head. For the standard head, machining time for each of the two parts of the casting that make up the head is around $40 \mathrm{~h}$, whereas, for the new head, this time is reduced to $18 \mathrm{~h}$ for each part owing to the omitting of most of the drilling operations.

Although the milling head was firstly fitted to a new milling machine as Dietmair et al. ${ }^{[27]}$ reported, the milling machine performance with the new milling head cannot be compared with previous results because this milling machine incorporates many innovative elements that the standard milling machine did not have. The new milling head was therefore fitted to a standard Axia milling machine from Nicolás Correa S.A. (Fig. 9). The Axia milling machine family is a floor type moving column milling machine. This machine has been designed with both

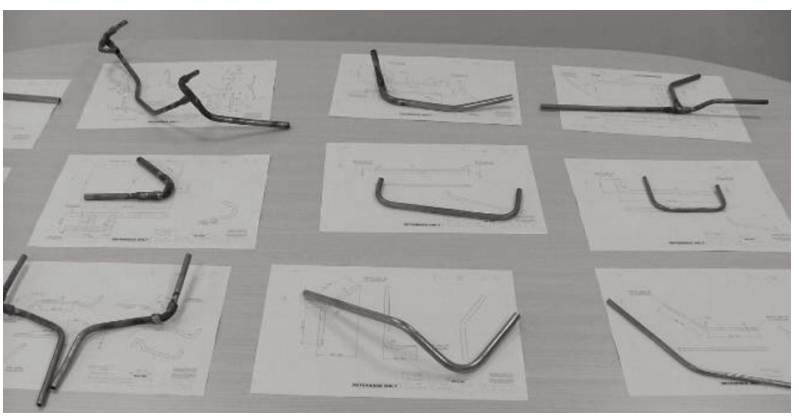

Figure 8. Tubular inserts.

Figura 8. Insertos tubulares finales. 
Table VIII. Comparison of machining times for new and standard heads

Tabla VIII. Comparación entre tiempos de mecanizado para el nuevo y el antiguo cabezal

\begin{tabular}{lcccccc}
\hline & \multicolumn{3}{c}{ Standard head (hours) } & \multicolumn{2}{c}{ New milling head (hours) } \\
\cline { 2 - 7 } Part & Milling & Drilling & $\begin{array}{c}\text { Auxiliary } \\
\text { operations }\end{array}$ & Milling & Drilling & $\begin{array}{c}\text { Auxiliary } \\
\text { operations }\end{array}$ \\
\hline Head body & 26 & 10 & 2 & 16 & 1 & 1 \\
Intermediate body & 28 & 14 & 2 & 16 & 1 & 1 \\
\hline
\end{tabular}

roughing and finishing capacities, mainly orientated to the general mechanics sector, which means an axis feed rate and acceleration of $30 \mathrm{~m} / \mathrm{min}$ and $1.2 \mathrm{~m} / \mathrm{s}^{2}$ respectively. It is equipped with a UAD standard milling head that can perform roughing and finishing operations on steel components.

Three tests were selected to validate the milling capabilities of the new milling head. Machine stiffness was firstly measured, followed by an analysis of the frequency response functions (FRFs) of the whole machine and further standard milling tests. The stiffness measurement and the analysis of the FRFs should clarify whether changes in the static or dynamic behaviour of the machine owing to the new milling head are significant. The milling tests should clarify whether the milling capabilities of the milling machines were diminished or remained the same.
Measurement of the stiffness at the end of the milling head (tool tip) was done by applying a force of known value in the three main orthogonal directions, $X, Y$ and $Z$, at the edge of the milling head. The applied force was measured with a dynamometer, calibrated in the range of between $2,000 \mathrm{~N}$ and $20,000 \mathrm{~N}$, the displacement of the milling head was measured with a micrometer comparator clock placed near the point where the force is applied. For the $X$ and $Z$-axes, stiffness in positive and negative directions was expected to be very similar, owing to design symmetry; therefore, stiffness was only measured in the positive direction. The measurement was done in the middle of the $X, Y$ and $Z$ travels of the machine, $X=4,000 \mathrm{~mm}, Y=600 \mathrm{~mm}$ and $Z=1,000 \mathrm{~mm}$ respectively, figure 9 shows the measurement results for the three machine axes. The (a)

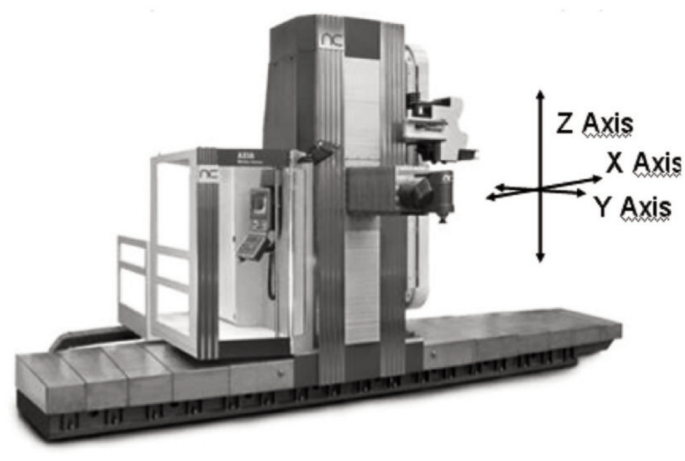

(b)

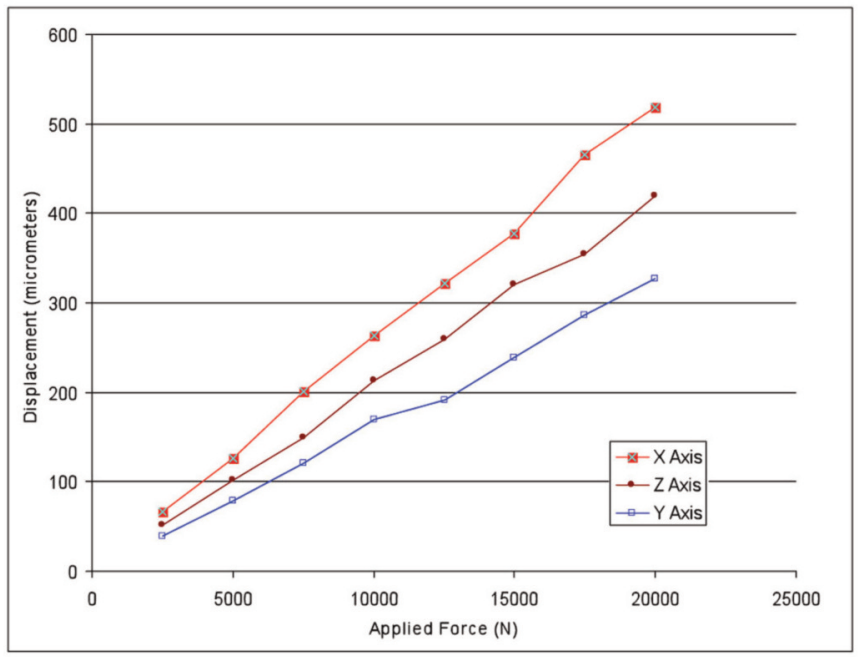

Figure 9. (a) Standard Axia milling machine and (b) stiffness of a standard Axia machine equipped with the new milling head in the $\mathrm{X}, \mathrm{Y}$ and $\mathrm{Z}$ axes.

Figura 9. (a) Fresadora estándar Axia y (b) rigidez de esta máquina equipada con el nuevo cabezal de fresado para los ejes $X, Y$ y $Z$. 
mean value of these results shows that the machine demonstrates an experimental stiffness of $38.45 \mathrm{~N} / \mathrm{um}$ on the $X$-axis, $47.85 \mathrm{~N} / \mu \mathrm{m}$ on the $Z$-axis and $61.35 \mathrm{~N} / \mathrm{um}$ on the $Y$-axis. Stiffness measurements for a standard milling machine are shown in table IX. It can be concluded that there are no significant differences in axis stiffness between the standard milling machine and one equipped with the new milling head. This result is reasonable considering other studies that conclude that the total stiffness of a milling machine is determined mainly by the stiffness of the other components of the milling machine apart from the head, considering the machine's mechanical errors like Dornfeld and Lee did ${ }^{[28]}$, tool deflection like Salgado et al. ${ }^{[29]}$ and machine stiffness like Rivin ${ }^{[30]}$ studied. Salgado et al. ${ }^{[29]}$ concluded that these factors may be considered if the head stiffness is greater than $62 \mathrm{~N} / \mu \mathrm{m}$ in the $Y$-axis, $33 \mathrm{~N} / \mu \mathrm{m}$ in the $X$-axis and $67 \mathrm{~N} / \mu \mathrm{m}$ in the $Z$-axis. The stiffness of the new head clearly exceeds these values in the three axes given that the total stiffness of the milling machine as a whole is around these values for the $Y$ - and $X$-axes, and that the stiffness in the $Z$-axis is determined mainly by the stiffness of the ram, which is the most flexible element on this axis of the machine.

The tests to obtain the FRFs of the machine were done by hitting the tool tip with a dynamometric hammer and measuring the acceleration response with an accelerometer placed on the head. This experimental test is a standard procedure to measure the FRFs of milling machines; Liu and Cheng ${ }^{[31]}$ used it to validate the modelling of the machining dynamics of peripheral milling and Zaghbani and Songmene ${ }^{[32]}$ referred to its use for natural frequency calculation of a milling machine to compare them during operation and stop mode. Figure 10 shows a comparison of the dynamic response of a standard Axia machine and the same machine equipped with the new milling head. As can be seen, the main natural frequencies and their amplitudes are in both cases not very different. The first main frequencies of the $\mathrm{X}$ and $\mathrm{Z}$-axes undergo a slight displacement of about $2.8 \%$ and $3.9 \%$ respectively, and there is no significant displacement for the $Y$-axis. These displacements are reasonable because the main eigenmodes for the $X$ and $Z$-axes are mainly caused by the flexion of ram, whereas the Y-Axis displacement is a result of machine column flexion, which means that it is not influenced by a change in the milling head. The weight reduction of the new milling head compared to the standard milling head may explain why the new modes are slightly displaced towards higher frequencies. Also, there is a nonsignificant increase in the frequency amplitudes for the $X$ and $Z$-axes, of about $1.2 \%$ and $1.4 \%$ respectively. This change could come from the reduced stiffness of milling head bodies but its influence in the total machine stiffness is almost negligible. The reason for this behaviour may reside in the fact that greater stiffness contributions come from machine component unions and from the least stiff component. The high stiffness obtained for the new milling head bodies and the high stiffness of the drive chain of this milling head ensures that the head still provides sufficient stiffness.

Finally, milling tests were performed to ensure the milling capabilities of the machine with the new milling head. A loss of stiffness can affect the milling capability of the machine, and especially its roughing capability. Therefore, a test at maximum milling head power was performed to assure that roughing capability had not been diminished. For this test, a block of Steel 1.2311 was cut with a SECO R220.530125-80 face mill (8 teeth and $125 \mathrm{~mm}$ in diameter). An axial depth of cut Ap of $5 \mathrm{~mm}$ with a radial depth of cut Ae of $100 \mathrm{~mm}$ was set at a milling head rotation speed $\mathrm{S}$ of $460 \mathrm{rpm}$ with an average feed rate of 1,500 $-1,800 \mathrm{~mm} / \mathrm{min}$. The test should produce around $25-30 \mathrm{~cm}^{3}$ of swarf per $\mathrm{KW}$ and minute. Tests on the $X$-direction and the $Y$-direction were done to verify performance on the main axes. Vibrations were

Table IX. Comparison of stiffnesses using an Axia milling machine for the new and standard heads

Tabla IX. Comparación de rigideces del nuevo y el antiguo cabezal montados sobre una fresadora Axia

\begin{tabular}{lcc}
\hline & $\begin{array}{c}\text { Machine with a } \\
\text { standard head }\end{array}$ & $\begin{array}{c}\text { Machine with the } \\
\text { new milling head }\end{array}$ \\
\hline$X$ axis stiffness $(\mathrm{N} / \mu \mathrm{m})$ & $37-40$ & 38,45 \\
Y axis stiffness $(\mathrm{N} / \mu \mathrm{m})$ & $45-48$ & 47,85 \\
$Z$ axis stiffness $(\mathrm{N} / \mu \mathrm{m})$ & $60-62$ & 61,35 \\
\hline
\end{tabular}




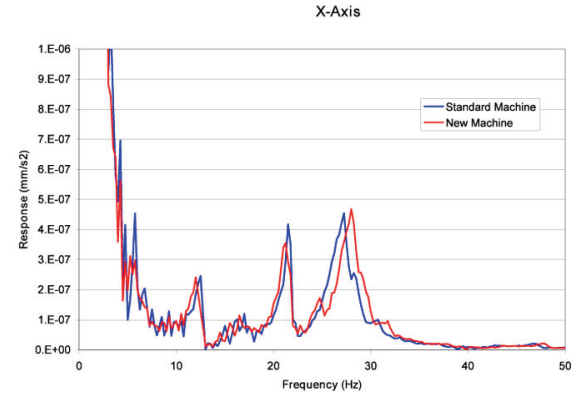

1)

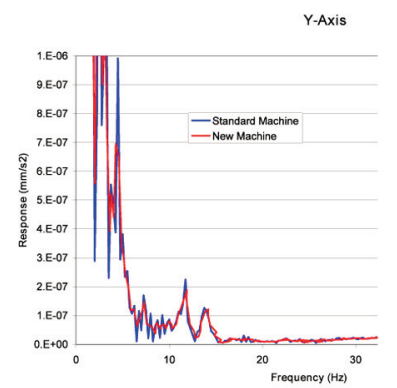

2)

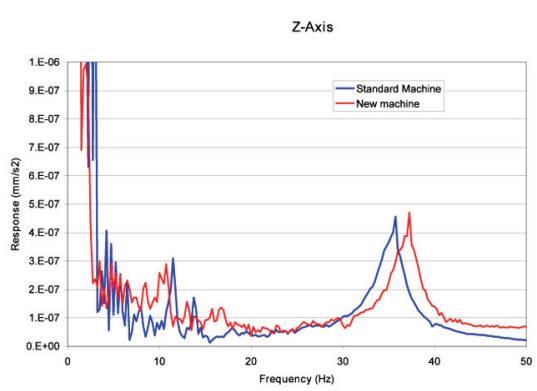

3)

Figure 10. Dynamic response of a standard Axia machine and the same machine equipped with the new milling head in the $X(1), Y(2)$ and $Z$ axes (3).

Figura 10. Respuesta dinámica de una fresadora Axia estándar y respuesta dinámica para la misma máquina equipada con el nuevo cabezal para los ejes $X(1), Y(2)$ y $Z$ (3).

measured on the $X$ and $Y$ directions during the tests to ensure that the maximum permitted levels of vibrations, established by the ISO 1940-1 standard ${ }^{[33]}$, were not surpassed. A feed rate of $1,300 \mathrm{~mm} / \mathrm{min}$ was programmed at the beginning of the test and was continuously increased until the machine cut out after reaching its maximum power. Table $\mathrm{X}$ and table XI respectively summarize the cutting conditions and the results for this test. Table XI also shows the expected swarf volume of the test for a standard milling head and the measured values for the new milling head. No significant difference could be found between the new and the standard milling head.

\section{CONCLUSIONS}

- This article has outlined a comprehensive methodology for designing and manufacturing high-performance mechanical transmission heads for milling machines. The methodology includes the making of head bodies with light alloys and the inclusion of metal tubular inserts in the casting of the head. The tubular inserts replace the cooling conducts currently created via machine drilling, which represents a significant fraction of the cost of head manufacture and also a reduction in reliability. The new methodology includes CAD design, FEM simulation of stiffness and thermal behaviour, PROCASTO simulation of the manufacturing process and feedback obtained from FRF tests.

- This new methodology was validated via the redesign of a commercially-available head. AS13UG alloy was chosen as the most suitable alloy for the head bodies as it proved to have good static, dynamic and thermal behaviours. Different base materials and coatings were tested for the tubular inserts with the stainless steel chosen based on its better results in experiments compared with other combinations. Head design was optimised maintaining the required geometric dimensions so that the new bodies are compatible with the rest of the standard head. The optimised head is $16 \%$ lighter than the standard head and complies with the thermal stability and mechanical stiffness requirements. The experimental tests undertaken with the new head confirm that it maintains the same milling capabilities as the standard head and improves the dynamic behaviour of the machine

Table X. Cutting conditions for milling head power test

Tabla X. Condiciones de corte para la prueba de carga del cabezal

\begin{tabular}{lccccccc}
\hline $\begin{array}{l}\text { Number } \\
\text { of teeth }\end{array}$ & $\begin{array}{c}\text { Tool } \\
\text { type }\end{array}$ & $\begin{array}{c}\text { Diameter } \\
\mathbf{m m}\end{array}$ & $\begin{array}{c}\text { Vc } \\
\mathbf{m m} / \mathbf{m i n}\end{array}$ & $\begin{array}{c}\mathbf{S} \\
\mathbf{r p m}\end{array}$ & $\begin{array}{c}\text { Feed rate } \\
\mathbf{m m} / \mathbf{m i n}\end{array}$ & $\begin{array}{c}\text { Ae } \\
\mathbf{m m}\end{array}$ & $\begin{array}{c}\mathbf{A p} \\
\mathbf{m m}\end{array}$ \\
\hline 8 & face mill & 125 & 181 & 460 & $1,300-1,800$ & 100 & 5 \\
\hline
\end{tabular}


NEW STRATEGY FOR THE OPTIMAL DESIGN AND MANUFACTURE OF HIGH PERFORMANCE MILLING HEADS NUEVA ESTRATEGIA PARA EL DISEÑO Y FABRICACIÓN DE CABEZALES DE FRESADORA DE ALTAS PRESTACIONES

Table XI. Standard expected swarf volume for milling head power test and measured values for new milling head

Tabla XI. Tasas de arranque de viruta para un cabezal estándar y para el nuevo cabezal diseñado

\begin{tabular}{lcc}
\hline & \multicolumn{2}{c}{ Swarf volume $\mathbf{c m}^{3} / \mathbf{m i n} . \mathbf{K W}$} \\
\cline { 2 - 3 } & Standard machine & Machine with the new milling head \\
\hline Test $X$ direction & $27-32$ & 28.32 \\
Test $Y$ direction & $27-32$ & 28.45 \\
\hline
\end{tabular}

in which it is incorporated as the reduction in weight transfers the first natural frequency to higher frequencies, owing to the flexion of the ram-head unit.

- Future research will adapt this methodology to boring heads and extend the study of materials compatible with the aluminium alloys and coatings to make the process of inserting the tubular inserts into the casting more flexible.

\section{Acknowledgements}

This investigation has been partially funded by the Spanish Ministry of Science and Innovation in the PROFIT Project FIT-020500-2006-50 and by the Agencia de Desarrollo Economico of the Junta de Castilla-Leon (04/06/BU/0008). The authors would especially like to thank Ing. Javier Hernando from Nicolas Correa S.A. for his kind-spirited and useful advice.

\section{REFERENCES}

[1] CECIMO Report 2009, Last trends in the European Machine Tool industry. Available at: http://www.cecimo.eu/index.php/machine-to.

[2] E. De Vries, Renewable Energy World Magazine, 10 (4) (2007) 1-10.

[3] R.M. del Toro-Matamoros, R.E. Haber, J. Palies and A. Bustillo, Rev. Metal. Madrid 44 (2008) 176-188

[4] D. Ancona and J. McVeigh, Wind Turbine Materials and Manufacturing Fact Sheet, Princeton Energy Resources International, 2001, pp. 1-8.

[5] P. Sekler, A. Dietmair, A. Dadalau, H. Rüdele, J. Zulaika, J. Smolik and A. Bustillo, WT-Online 5 (2007) 320-327.
[6] A. Dietmair, A. Verl and P. Eberspächer, Int. J. Manuf. Res. 6 (2011) 380-327.

[7] A. Dietmair and A. Verl, IEEE International Conference on Sustainable Energy Technology (ICSET), Singapore, 2008, pp. 524-579.

[8] J.A.W. Hijink and A.C.H. Van Der Wolf, $14^{\text {th }}$ International Advances in Machine Tool Design and Research Conference, Manchester, England, 1973, pp. 553-558.

[9] S. Taylor and S.A. Tobias, $5^{\text {th }}$ International Advances in Machine Tool Design and Research Conference, Birmingham, England, 1964, pp. 37-44.

[10] H. Sato, Y. Kuroda and M. Sagara, $14^{\text {th }}$ International Advances in Machine Tool Design and Research Conference, Manchester, England, 1973, pp. 545-552.

[11] D.Te-Yen Huang and J.J. Lee, Int. J. Mach. Tools Manuf. 41 (2001) 1149-1163.

[12] Y.M. Zhang, X.L. Lin, X.D. Wang and G.Q. Cai, Mater. Sci. Forum, 471-472 (2004) 765-769.

[13] L.N. Lopez de Lacalle and A. Lamikiz, Machine Tools for High Performance Machining. (Ed.) Springer Verlag, 2009, pp. 58-60.

[14] N. Amaral, J.J. Rencis and Y.M. Rong, Int. J. Adv. Manuf. Technol. 25 (2005) 409-419.

[15] M. Rantatalo, J. Aidanpää, B. Göransson and P. Norman, Int. J. Mach. Tools Manuf. 47 (2007) 1034-1045.

[16] Q.D. Yang, G.Q. Liu and K.S. Wang, Chin. J. Mech. Eng. 21 (2008) 103-107.

[17] J. Smolik, $6^{\text {th }}$ International Conference on High Speed Machining, San Sebastian, Spain, 2007, pp. 467-472.

[18] J.C. Love and V. Goodship, Multi-Material Injection Moulding. Smithers Rapra Technology, Shawbury (UK), 2002, pp. 9-22.

[19] Z.Y. Liu, D. Kent and G.B. Schaffer, Mater. Sci. Eng. A, 513-514, (2009) 352-56.

[20] D.F. Heaney, P. Suri and R.M. German, J. Mater. Sci. 38 (2003) 4869-4874. 
[21] P. Imgrund, A. Rota, F. Petzoldt and A. Simchi, Int. J. Adv. Manuf. Technol. 33 (2007) 176-186.

[22] Z.Y. Liu, D. Kent and G. B. Schaffer, Trans. A-Phys. Metall. Mater. Sci. 40A-12 (2009) 2785-2788.

[23] S. Mattei, A. Mathieu, A. Deschamps, B. Martin and D. Grevey, NDTE Int. 39 (2006) 272-276.

[24] F.W. Bach, A. Beniyash, K. Lau and R. Versemann, Adv. Mater. Res. 6-8 (2005) 143-150.

[25] P. Bertrand, Nomenclature International des Alliages d'Aluminium de fonderie. Editions techniques des Industries de la fonderie, Paris, 1986, pp. 34-37.

[26] P.J. Mikelonis, Foundry technology Source Book. American Society for Metals, Illinois, EE.UU., 1982, pp. 119-123.

[27] A. Dietmair, J. Zulaika, M. Sulitka, A. Bustillo and A. Verl, $17^{\text {th }}$ CIRP International Conference
On Life Cycle Engineering (LCE), Anhui, China, 2010, pp. 105-110.

[28] D. Dornfeld and D.Lee, Precision manufacturing. Springer Verlag, New York, EE.UU., 2008, pp. 37-49.

[29] M.A. Salgado, L.N. Lopez de Lacalle, A. Lamikiz, J. Muñoa and J.A. Sánchez, Int. J. Mach. Tools Manuf., 45 (2005) 727-739.

[30] E. Rivin, Stiffness and damping in mechanical design, Marcel Dekker Inc.,1999, pp. 273-288.

[31] X. Liu and K. Cheng, Inter. J. Mach. Tools Manuf. 5 (2005) 1301-1320.

[32] I. Zaghbani and V. Songmene, Inter. J. Mach. Tools Manuf. 49 (12-13) (2009) 947-957.

[33] Norm ISO 1940-1, Mechanical vibration Balance quality requirements for rotors in a constant (rigid) state - Part 1: Specification and verification of balance tolerances. 